Vol. 2, No. 06; 2019

ISSN: 2581-4664

\title{
THE EFFECT OF TRANSFORMATIONAL LEADERSHIP ON EMOTIONAL INTELLIGENCE AND EMPLOYEE PERFORMANCE : STUDY IN KPO PT. BANK ACEH SYARIAH
}

\author{
*Daniel Kurniawan, Muhammad Adam and Sofyan Idris \\ Department of Management, Univeristas Syiah Kuala, Indonesia \\ http://doi.org/10.35409/IJBMER.2019.2427
}

\begin{abstract}
This study is to determine: (1) the effect of transformational leadership on emotional intelligence of Employees; (2) transformational leadership on employee performance, and; (3) emotional intelligence on employee performance. The object is the Operational Head Office (KPO) PT. Bank Aceh Syariah in Banda Aceh and the respondent is its employees. Census method is used to determine the amount of the sample so it provides 183 people as a sample. As this research model is a causality, to analyze the data it is used structural equation modeling (SEM) with AMOS software. The result shows that Transformational leadership influences emotional intelligence significantly, and Transformational leadership influences employee performance significantly, and Emotional Intelligence influences employee performance significantly. The causality results contribute to academic that these all can be updates for causality theories to be new premises, and can be develop in the next research by another researchers. The originality is in the integration of the models that is taken from several previous research. These all findings has an implication to managers especially related to KPO PT. Bank Aceh Syariah to pay more attention about the causality among variables in this research. The limitation of this research lies in the number of variables and object.
\end{abstract}

Keyword: Transformational leadership, emotional intelligence, employee performance.

\section{INTRODUCTION}

In order to encourage the improvement in employee performance at Operational Head Office (KPO) of PT. Bank Aceh Syariah, it needs qualified human resources (HR) with the quality and the qualifications as it is expected. The talent of superior human resources is expected to be able to move the organization to achieve the vision, mission, and objectives of the company.

The improvement in employee performance can be achieved if it involves supporting factors, namely job satisfaction, transformative leadership style and the application of corporate or organizational culture that is respected by all individuals. It is expected that company can play its role in integrating organizational goals with employee perspectives.

Transformative leadership can encourage the achievement of corporate goals in general. In this approach, employees are directed to be able to manage with dedication and loyalty to their work, with clearer guidance and direction and better coordination with their subordinates. We 


\section{International Journal of Business Management and Economic Review}

Vol. 2, No. 06; 2019

ISSN: 2581-4664

see that in this era of globalization, multinational companies and monolithic organizations can be considered equal to countries in their own right. These organizations, because of their size and thin history, have developed a culture that is driven by their own competence. The culture is driven by the competencies that have been shaped by the history of their respective experiences and leaders who dedicate policies in maximizing employee performance.

Management transformation in the object of research, namely PT Bank Aceh Syariah, will have an impact on changes in job satisfaction and employee performance. Therefore, the authors think it is important to measure the effects of these changes on the continuity of the vision from the object of research in the long term. In particular, this management change will have an impact on all organizations and employees.

There are a number of benefits from applying the right leadership style. A good leadership style can contribute to the effectiveness of company management. In addition, because it is able to increase or motivate employees to work, a good leadership style also contributes to increase employee productivity (Bass and Riggio, 2006). In the understanding, the concept of charisma in leadership is introduced in which charismatic leaders are considered to have a very significant influence on their subordinates. (Bass and Riggio, 2006) illustrate that transformational leadership is a process of developing an integrated level of morality and motivation from all individuals in the company, from the leadership level to the employee level.

(Bass and Riggio, 2006) show that transformational leader is someone who creates charismatic leadership, inspirational leadership, intellectual stimulation and the feeling that all subordinates must be brought into one team and one goal. (DuBrin, 2012) explains that transformational leaders will be able to encourage, use values, trust and can fulfill the desires of subordinates. Leaders who do it in situations that change quickly are called charismatic leaders. Charismatic leaders can implement corporate behavior and culture that is adapted to the dynamics within the organization. In relation to this study, it is expected that through transformative leadership it can gradually encourage an increase in employee performance.

\section{LITERATURE STUDY}

\section{Employee Performance}

Performance according to (Timpe, 2002) is a result or level of achievement from individuals in a group that contributes to increase the productivity of the group. (Van Hoek, 1999) explains that performance can be defined as the personal success of an employee in carrying out his obligations which can vary between individuals.

Meanwhile the definition of employee performance which is proposed by (Siagian, 2014) focuses more on the comparison of target achievement with the sacrifices that are made by individuals from the activities they do for companies or organizations. If the results which are achieved are greater than the sacrifice, the performance of the employee can be considered satisfactory and vice versa.

Furthermore, (Timpe, 2002) divides the elements that can influence employee performance to two elements, which consist of:

a. Internal elements, related to individual personality. They include attitudes, personal traits, physical and desires; and other demographic things such as gender, educational background, culture, and so on. 


\section{International Journal of Business Management and Economic Review}

Vol. 2, No. 06; 2019

ISSN: 2581-4664

b. External elements, related to the environment around the organization or company where the employee works.It includes the attitudes and behaviors of peers, the reward and compensation system, the training and supervision model that is implemented, leadership patterns and organizational policies, and so on.

Furthermore, the factors that can have an impact on the merits of company performance are also expressed by (Pasolong, 2008), which consists of:

a) Skills, namely a set of proficiency in a particular expertise, which are related to individual interests, intelligence and talents.

b) Desire, namely willingness to provide the highest sacrifice for the progress of the company.

c) Compensation, namely an award or remuneration to individuals for the achievements which they have presented to the company.

d) Technology, namely the application of science and knowledge in simplifying certain work processes.

e) Clear direction and goals, which individuals can strive so that the achieved performance can be effective and efficient in accordance with the interests of the organization.

f) Energy, in this case includes the ability of individuals to respond to problems that occur in their work responsively so that any obstacles which are encountered do not interfere with their concentration and mentality because it can influence the performanceof company.

g) Security, namely the most basic human need that can encourage the merits of individual performance in an organization.

\section{Transformational Leadership}

In each organization, we can find a variety of leadership styles. Whether the application of a leadership style in an organization is suitable or not, itdepends on various aspects. The selection of the right leadership style besides being able to encourage employee motivation in work, it can also encourage the increase in employee productivity (Bass and Riggio, 2006).

One approach in leadership style accommodates the concept of charisma in leadership. This concept by (Bass and Riggio, 2006) is referred to as transformational leadership, in which charismatic leaders have a very significant influence on their subordinates. In this approach, leaders and subordinates develop an integrated level of morality and motivation. In addition, charismatic leaders are described as someone who creates inspirational leadership, intellectual stimulation and the feeling that all subordinates must be brought into one team and one goal.

(DuBrin, 2012) explains that transformational leaders will be able to encourage, to use values, to use trust and to fulfill the desires of subordinates. The leaders who do so in rapidly changing situations are called transformational crisis leaders. Transformational leaders can succeed in shifting the status quo of an organization by implementing appropriate policies at each stage of change. When old policies cannot keep up with the times, it is when leaders must be able to direct the organization to new vision, mission and goals.

Leadership is an effort to influence individuals to achieve common goals through processes including communication. While the right leader is able to mobilize, encourage, and 


\section{International Journal of Business Management and Economic Review}

Vol. 2, No. 06; 2019

ISSN: 2581-4664

motivate organizational members dynamically to achieve common goals. In addition, the right form of leadership style can motivate employees to achieve higher achievements. Therefore, a charismatic leader is needed in encouraging the increase in motivation and a stronger work culture. In a previous study which is conducted by (Yiing and Ahmad, 2009), (Dan et al., 2014), itis found an effect of leadership style on improving employee performance and organizational performance in general.

\section{Emotional Intelligence}

According to (Salovey and Mayer, 1990), emotional intelligence is an ability to control feelings and emotions of his and others, and to sort out between them, so that the information can be utilized in managing individual thoughts and actions. In this understanding, emotional intelligence can be interpreted as an individual awareness of his own emotions and skills in expressing those emotions. Furthermore, emotional intelligence factor by (Goleman, 2002) is seen as an ability of individual to regulate his emotions with intelligence that he has which includes the following five basic skills:

1) Sensitive in identifying self-emotions

2) Skilled in controlling emotions

3) Able to motivate oneself

4) Able to identify the emotions of other people

5) Skilled in establishing relationships with other people

\section{Conceptual Framework}

The conceptual framework in this study can be described in figure below:

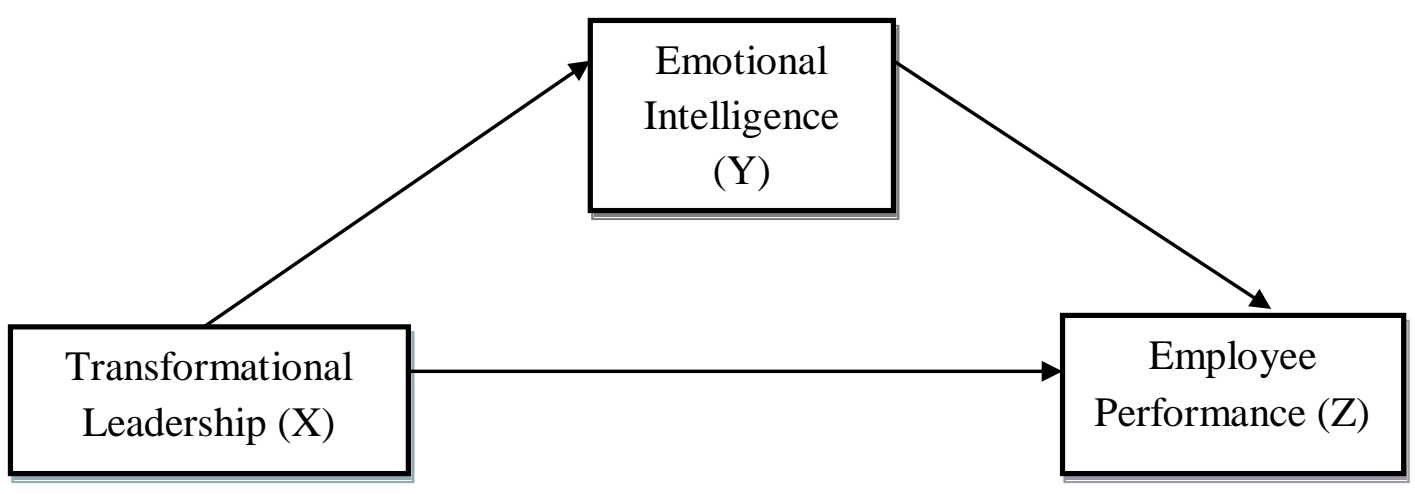

Figure 1.Framework Model 
International Journal of Business Management and Economic Review

Vol. 2, No. 06; 2019

ISSN: 2581-4664

\section{Hypothesis}

H1 : Transformational leadership influences emotional intelligence significantly.

H2 : Transformational leadership influences employeeperformance significantly.

H3 : Emotional Intelligence influences employeeperformance significantly

\section{RESEARCH METHOD}

The study is carried out in Operational Head Office (KPO)at PT. Bank Aceh Syariah. Census method is used to determine the amount of the sample, so the sample takes all population, there are 183 people of all employees KPO PT. Bank Aceh. Asthis research model is a causality, to analyze the datait is used structural equation modeling (SEM). As it is stated by (Ferdinand, 2006), a structural equation model (SEM) is a series of statistical techniques that can test the relationship of relatively complex relationships simultaneously. The application to run SEM is Amos 23.

\section{RESULT}

After the indicators form latent variable through the uni-dimensionality testing stage with confirmatory factor analysis, a full model of SEM analysis is performed. The output of the full model of SEM analysis is presented in Figure 1 below:

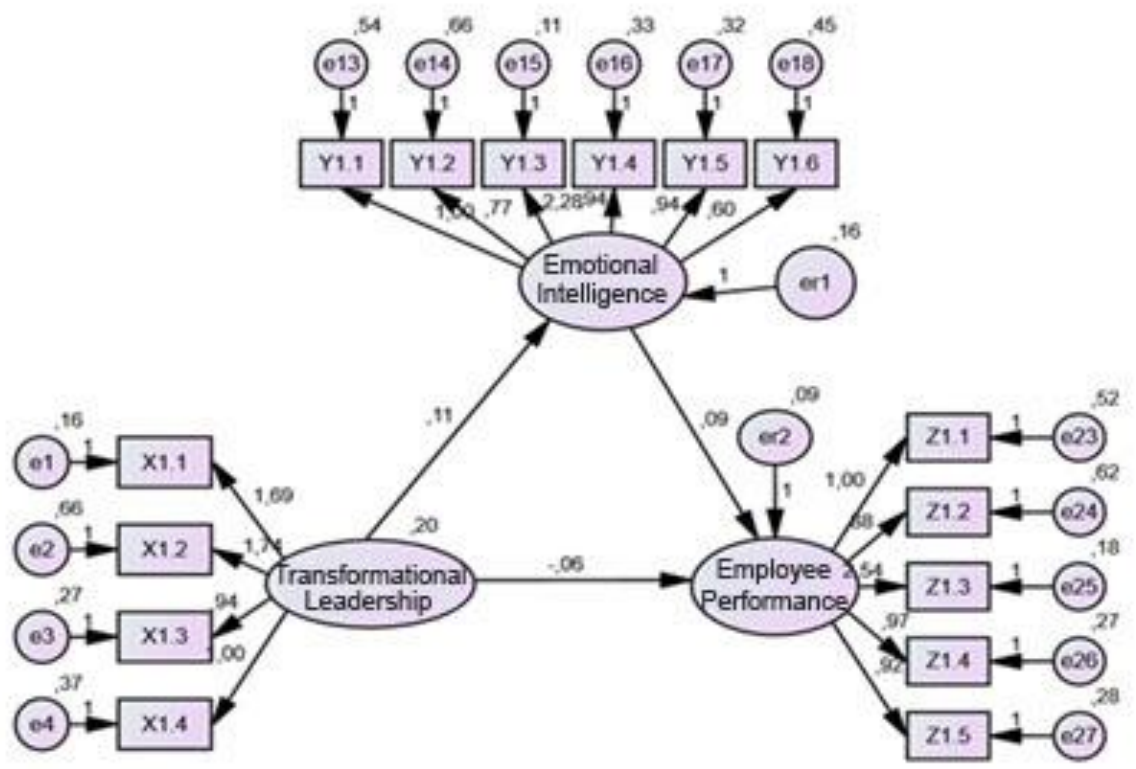

Figure 2. Output of Structural Equation Model (SEM) Analysis

The coefficient between variables, the information also provides in the table below. 


\section{International Journal of Business Management and Economic Review}

Vol. 2, No. 06; 2019

ISSN: 2581-4664

Table 1. Coefficient of Effects between Variables

\begin{tabular}{|c|c|c|c|c|}
\hline No & Variable & $\begin{array}{c}\text { Direct of } \\
\text { Effect }\end{array}$ & Variable & $\begin{array}{c}\text { Estimat } \\
\mathrm{e}\end{array}$ \\
\hline 1 & $\begin{array}{c}\text { Emotional } \\
\text { Intelligence }\end{array}$ & $<---$ & $\begin{array}{c}\text { Transformational } \\
\text { Leadership }\end{array}$ & .111 \\
\hline 2 & $\begin{array}{c}\text { Employee } \\
\text { Performance }\end{array}$ & $<---$ & $\begin{array}{c}\text { Emotional } \\
\text { Intelligence }\end{array}$ & .088 \\
\hline 3 & $\begin{array}{c}\text { Employee } \\
\text { Performance }\end{array}$ & $<---$ & $\begin{array}{c}\text { Transformational } \\
\text { Leadership }\end{array}$ & .061 \\
\hline
\end{tabular}

Source: Primary Data, 2018 (Processed)

\section{H1 is accepted: The Effect of Transformational Leadership on Emotional Intelligence}

From the results of the analysis, the effect of transformational leadership on emotional intelligence obtains CR value of 3.828 and a probability of 0.000 . From the acquisition of these values, the conditions for receiving $\mathrm{H} 1$ are fulfilled, namely $\mathrm{CR} \geq 1.97$ and probability $\leq 0.05$. Thus, transformational leadership at PT. Bank Aceh Syariah influences the increase of emotional intelligence of PT. Bank Aceh Syariah.

\section{H2 is accepted :The Effect of Emotional Intelligence on Employee Performance}

The effect of emotional intelligence on employee performance shows CR value of 3.034 and a probability of 0.000 . Thus it can be concluded that the emotional intelligence which is produced can have an influence on improving employee performance at PT. Bank Aceh Syariah.

\section{H3 is accepted : The Effect of Transformational Leadership on Employee Performance}

The estimated value for testing the effect of transformational leadership on employee performance shows CR value of 2.652 and a probability of 0.000 . Thus it can be concluded that transformational leadership at PT. Bank Aceh Syariah has an effect on improving employee performance. From this result, it can explains with the better transformational leadership will encourage improvement in employee performance.

The study result confirms the research conducted by (Alia, Darsono and Idris, 2018) that emotional intelligence of employees has an effect in improving employee performance. Next, the study results are consistent with the study of (Zulkifli, Mukhlis and Mahdani, 2018) proved that transformational leadership has an effect in improving employee performance in the Regional Secretariat of Aceh. The research resultof (Irmalizar, Amri and Bahri, 2018) also find that transformational leadership has an effect on improving employee performance.

Then emotional intelligence also has an effect on improving employee performance, with the performance which is produced by employees, they will increasingly have an emotional bond with the organization. The study result confirms the research which is conducted by (Mitchell et al., 2001)found that employee performance will describe how an employee is tied to the job and the company where he works because of the influence of aspects that are related to the work and other aspects. 


\section{International Journal of Business Management and Economic Review}

Vol. 2, No. 06; 2019

ISSN: 2581-4664

\section{CONCLUSION}

The result shows that Transformational leadership influences emotional intelligence significantly, and Transformational leadership influences employeeperformance significantly, and Emotional Intelligence influences employeeperformance significantly. The causality results contribute to academic that these all can be updates for causality theories to be new premises, and can be develop in the next research by another researchers. The originality is in the form of the model, that this is an integration model from several ones in the previous research. These all findings has an implication to managers especially related to KPO PT. Bank Aceh Syariah to pay more attention about the causality among variables in this research. This can be a reference to build the right policies and implement the strategies in the further. The limitation of this research lies in the number of variables and object.

\section{REFERENCES}

Alia, N., Darsono, N. and Idris, S. (2018) 'Organizational Citizenship Behavior Dan Kinerja Sekretariat Dewan Pengurus Korpri Aceh’. Banda Aceh: Universitas Syiah Kuala. Available at: http://etd.unsyiah.ac.id/index.

Bass, M. B. M. and Riggio, E. R. (2006) Transformational Leadership. New Jersey: Lawrence Erlbaum Associates.

Dan, N. H. et al. (2014) 'An Empirical Study Of The Organizational Culture, Leadership And Firm Performance In A Vietnam Family Business', International Journal of Organizational Innovation, 6(4), pp. 109-121.

DuBrin, A. J. (2012) Essentials of Management. 9th Editio. Ohio: Cengage Learning. Ferdinand, A. (2006) Metode Penelitian Manajemen Pedoman Penelitian untuk Penulisan Skripsi Tesis dan disertai Ilmu Manajemen, Semarang: Universitas Diponegoro. Semarang: Fakulas Ekonomi dan Bisnis Univ Diponegoro.

Goleman, D. (2002) Kecerdasan Emosi Untuk Mencapai Puncak Prestasi. Jakarta: Gramedia. Van Hoek, R. I. (1999) 'The Horizontal Organization', Supply Chain Management: An International Journal. doi: 10.1108/scm.1999.4.5.254.1.

Irmalizar, Amri and Bahri, S. (2018) 'Dampak Kinerja Pelayanan, Perceived Value, Dan Kepercayaan Terhadap Loyalitas Yang Dimediasi Oleh Kepuasan Nasabah Bri Syariah Cabang Banda Aceh'. Banda Aceh: Universitas Syiah Kuala. Available at: http://etd.unsyiah.ac.id/index.

Mitchell, T. R. et al. (2001) 'Why people stay: Using job embeddedness to predict voluntary turnover', Academy of Management Journal, 44(6), pp. 1102-1121. doi: 10.2307/3069391.

Pasolong, H. (2008) 'Teori Administrasi Publik, Alfabeta'. Bandung.

Salovey, P. and Mayer, J. D. (1990) Emotional Intelligence. New York: Baywood Publishing. Siagian, S. P. (2014) Manajemen Sumber Daya Manusia. Jakarta: Bumi Aksara.

Timpe, A. D. (2002) Seri Ilmu dan seni Manajemen Bisnis (Memimpin Manusia). Jakarta: Gramedia.

Yiing, L. H. and Ahmad, K. Z. Bin (2009) 'The moderating effects of organizational culture on the relationships between leadership behaviour and organizational commitment and between organizational commitment and job satisfaction and performance', Leadership and Organization Development Journal, 30(1), pp. 53-86. doi: 
International Journal of Business Management and Economic Review

Vol. 2, No. 06; 2019

ISSN: 2581-4664

$10.1108 / 01437730910927106$.

Zulkifli, Mukhlis and Mahdani (2018) 'Pengaruh Gaya Kepemimpinan Transformasional Dan Transaksional Terhadap Kinerja Pegawai Serta Dampaknya Pada Kinerja Setda Aceh'. Banda Aceh: Universitas Syiah Kuala. Available at: http://etd.unsyiah.ac.id/index. 